Phys. Comm.3(1)(2019)21-28
Physics Communication
Uttp://journal.unnes.ac.id/nju/index.php/pc

\title{
The Profile of Physical Problem-Solving Based on Student's Personality Types
}

\author{
Ragil Meita Alfathy $\bowtie$, Budi Astuti, Suharto Linuwih
}

Pascasrjana, Universitas Negeri Semarang, Indonesia

\section{Article Info}

Article History:

Submitted:

July, 302018

Accepted:

September, 142018

Published:

September, 142018

Keywords:

Problem solving, Problem solving pattern, Personality type.

\begin{abstract}
Problem solving is important for learning physics at any level which involves the process of analysing, interpreting, reasoning, predicting, evaluating and reflecting. However, researches about problemsolving strategies or techniques based on students' personality have not been widely practiced. This strategy is important to be studied based on thoughts, characters and actions of students. Therefore, the aims of the research are to connect students problem solving of physics based on their personality and identify students problem solving pattern based on their personality according to The Four Temperament Theory of Keirsey (1998). The method used in this research is descriptive qualitative research with the type of Investigation of Lived Experience that explores inner experiences (Gall et al, 2003). Subjects in this study are $12^{\text {th }}$ grade students of science class program of MAN 1 Banyumas which is determined by stratified sampling approach. They were divided into homogeneous groups. The grouping is based on Keirsey's four personality types: Idealist, Artisan, Guardian and Rational. Each personality type, selected nine students as research subjects are determined using purposive sampling technique. The results showed that the strategy of physics problem solving of Idealist type was conceptual problem solving, Artisan type used intuitive-analogic for solving the problem, Guardian type used intuitive for solving the problem, and Rational type used analogic strategy for solving the problem.
\end{abstract}




\section{INTRODUCTION}

The existing researches about problem solving based on personality types has been widely practiced (Jackson, 2011; Pertiwi et al., 2014; Panjaitan, 2015; Zanberg et al., 2016). In fact, there is no research which reveal specific problem solving strategies or techniques in each personality types, if the strategy sorted will form a systematic pattern. This strategy is important to examine based on the opinion of Olson \& Hergenhahn (2013) which explained that each individual has certain uniqueness in the form of thoughts, characters and actions. The unique personality was due to the birth genes and the current formation of personal experiences which was called as personality.

The problem solving and decision making patterns include at least four phases (Bransford \& Stein, 1984; Dewey, 1933; Polya, 1971): (1) input phase, where problems were understood and alternatives were made to understand the situation or problem; (2) the processing phases where alternatives were evaluated and solutions were selected; (3) the output phase which includes the planning and application of the solution; and (4) the evaluation phase that the solution is evaluated and modified, if necessary. The role of personality in decision making was explained by Surya (2015), that the process of thinking in problem solving and decision making was influenced by internal and external factors of students. These factors affect the reception of information, processing, storage and retrieval of information from student's memories. External factors included the reception of information which was influenced by the surrounding environment or personal experience was experienced by students (Brunning et al., 2012; Akse et al, 2016). From the student self-aspects or internally, the acceptance of information depended on the characteristics of the person causing the emergence of consistency of feelings, thoughts and character (Pervin et al, 2010).

The character was further described by Keirsey (1998) in his book of Please Understand Me II. Keirsey (1998) linked and formulated the similarity of characters from the previous scholar theories and characterize the personality in four types, namely Idealist, Artisan, Guardian and Rational were known as The Four Temperament Theory. The classification based on the four dichotomies of mental functions or attitudes, about how individuals view information, how individuals provide judgments or decisions according to their perceptions, how to make use of their time and energy, and how the basic lifestyle of individuals in their environment (Jessee et al, 2016).

Each personality type will certainly have its own character expressing his ideas both orally and in writing. Therefore, the success of individuals in the field of academics, especially in the field of physics can be improved by providing specific techniques that suit the individual style. So, the purposes of this research are to link the model problem solving process with personality type theory to facilitate problem solving by focusing on individual differences and identify the specific technique differences that individuals use in individual decision making or decision processes according to The Kersey's Four Temperament Theory (1998).

\section{METHOD}

The research method was qualitative research method. The type of qualitative research used in this research was the type of Investigation of Lived Experience with Cognitive Psychology type (Gall et al., 2003). Research Investigation of Lived Experience is a qualitative research that explores inner experience about perception, memory, attention, thinking ability and problem solving.

\section{Research Subjects}

Data sources in this research were the respondents who were determined by using purposive sampling technique with stratified sampling approach, which divided the students of Sciences Programme of MAN 1 Banyumas into homogeneous groups based on four Keirsey (1998) personality types: Idealist, Artisan, Guardian, and Rational types. Each personality type was chosen 
by nine students as research subjects using Purposive Sampling technique, by considering criteria: (1) personality type, (2) activity during physics study and (3) completeness of written test result.

\section{Data Collection}

All data used in the study was the primary data obtained directly from the subjects. The instrument include: (1) Questionnaire, this instrument is available in Keirsey's book titled Please Understand Me II and were modified by researcher to align with conditions in Indonesia. This questionnaire consists of 16 questions with 4 answer choices. The answer choices was sorted by subject according to student's individual for grouping them according to Keirsey's (1998) Personality Types which is type Idealist, Artisan, Guardian and Rational. (2) Written tests, which consisted of two problems regarding the analysis of the interaction of force and mass on sloping plane and slippery plane and the identification of the application of Newton's II law principle in everyday life in the form of reasoning multiple choice for illustrating students how to answer questions and avoid any answers that stray far from the topic of the problem, and (3) Interview, which was done to the students on the next meeting after answering the written question to confirm and disclose the findings about student's problem solving and problem solving pattern with questions related to how students answer questions and their reasons in written test.

\section{Data Analysis}

Data analysis used fixed comparison method. Moleong (2002) explained the process of data analysis of comparison method using the steps of: (1) data processing, (2) data reduction, (3) categorization and coding, and (4) make conclusions.

\section{Data Validity}

Data in qualitative research must meet the requirements of transferability, dependability and conformability. Term of transferability was obtained by describing the data in detail. Term of dependability was obtained by taking 36 respondents with different personality types. Term of conformability was obtained by making interview guidelines, making a grid of test questions, and presenting the data according to the results found.

\section{RESULT AND DISCUSSION}

Techniques for each step in the problem-solving pattern will be presented in the context of group problem-solving situations but are equally applicable to individual situations reviewed based on Dewey's five problem-solving indicators.

\section{The Idealist Pattern of Physics Problem Solving}

Idealist students tend to have the ability to determine related concepts to solve the problems, which are then named as conceptual problem-solving patterns. I-5 can solve problem 3 about related to the application of Newton's law principle II in daily life about the phenomenon that makes the object seems to lose some of its mass. The result of interview with I-5 shows in excerpts of an interview below.

$R:$ if, on earth there must be a gravity whose style leads to the center of gravity in the earth. I answered $D$, when in the elevator that moves down. When people in the elevator, its means the downward acceleration, then the gravity is going down towards the center of gravity in the earth. Then here, there is a mass of people, that's meaning there is a normal force upward that is positive then the weight is negative. Then the normal force minus weight minus acceleration equal to zero. Then the weight is equal to the normal force minus acceleration. If the elevator moves upward it means that the weight is actually equal to normal force added to the acceleration itself, so it will be even heavier.

$A$ : so what is the conclusion? 
$R$ : when in a downward moving elevator it's the same way to lose some weight.

Based on the excerpt of the interview can be revealed in general, the pattern of Idealist problem solving that presented in Figure 1.

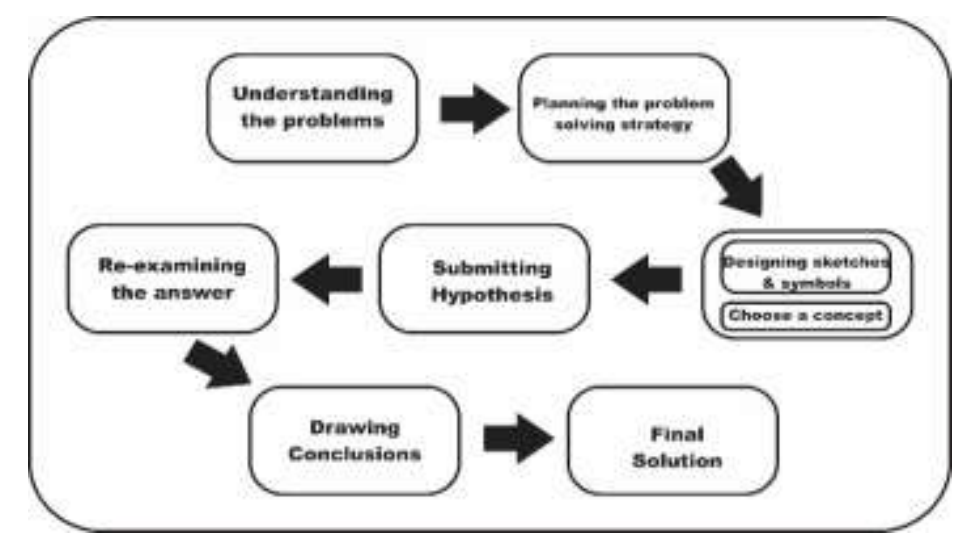

Figure 1. Idealist Problem Solving Patterns of Physics

\section{The Artisan Pattern of Physics Problem Solving}

Artisan students have a tendency to complete a problem-solving plan using a combination of intuition and analogy, which further called an intuitive-analogic problem-solving pattern. This is shown in the result of written test A- 6 on problem 3 related to the application of Newton's law principle II in daily life about the phenomenon that makes the object seems to lose some of its mass. Here are excerpts of the interview with A-6 on problem 3.

$R$ : I think, when jump from high-rise building. Because cause, there is no weight, it feel light. So there is no effect of gravity.

$A:$ Are you sure?

$R:$ for example, when we are in the elevator, we're still treading on the elevator, so we still felt the weight. Next option is, someone who swung himself too, he was up and down, the gravity still influence them that makes they back in the opposite direction after the push, of course the weight is still same. So the answer that most appropriate that $E$, when jumping from high-rise buildings.

Based on the excerpt of the interview, it can be revealed in general the pattern of Artisan problem solving that presented in Figure 2.

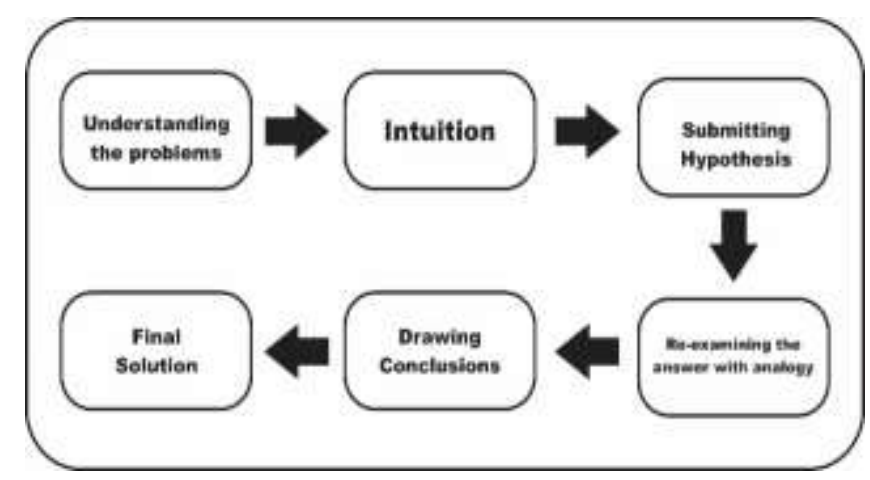

Figure 2. Artisan problem Solving Patterns of Physics 
Artisan students, who have an intuitive-analogic problem-solving pattern, have a difficult tendency to express the exact concept in every physics problem solving. This made Artisan students choose to intuit to draw hypotheses and analogy strategies to reinforce the hypothesis. Problem solving using intuition means that students do not do any planning in answering the problem.

\section{The Guardian Pattern of Physics Problem Solving}

Guardian students have a tendency to complete a problem-solving plan using intuition. It is shown in the result of G-3 work on problem 7 relating to an object in the slippery field, the student is asked to find a solution to move the object with the lowest force value. The following is an excerpt of an interview with G-3 on Problem 7.

$R: \quad$ because it is easier to pull than push because it's heavier

A: $\quad$ how did you know it's heavier?

$R$ : $\quad$ because squatting or sitting is heavier than standing

A: $\quad$ there is $60^{\circ}$ and $53^{\circ}$, why you choose $60^{\circ}$ ?

$R$ : $\quad$ because the angel is wide, it's like parallel to the foot

A: $\quad$ parallel to the foot? What do you mean?

$R: \quad 53^{\circ}$ was shortness so, maybe it will more easily with $60^{\circ}$

Based on the excerpt of the interview, here given the syntax of Guardian problem-solving pattern that presented in Figure 3.

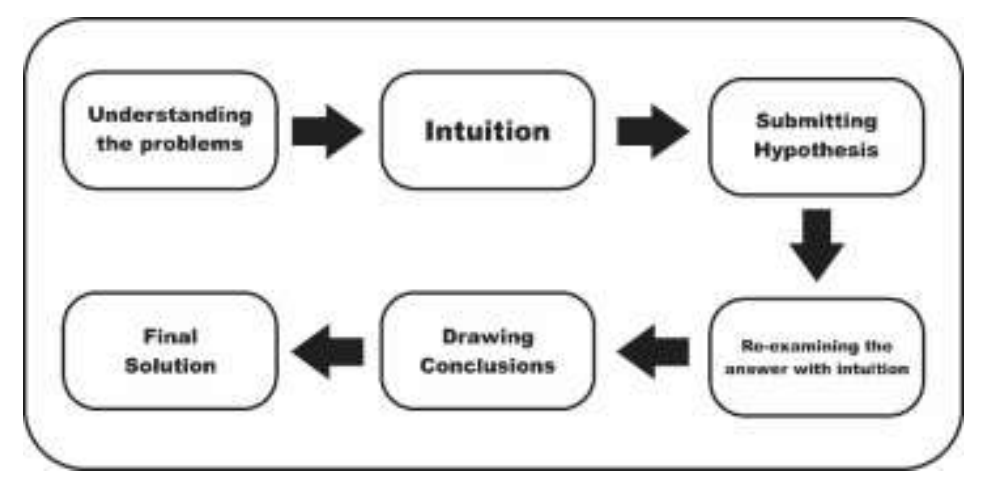

Figure 3. Guardian Problem Solving Patterns of Physics

Guardian students have intuitive problem-solving patterns that are almost identical to Artisan students. The difference is, the Guardian students take the hypothesis as the final solution after intuition. Some students re-examine on initial answers or hypotheses, but still use intuition with true and false boundaries. In this section lies the difference between the Guardian and Artisan students. While both equate to the hypothesis of intuition, the Artisan type tends to re-examine answers using analogy. 


\section{The Rational Pattern of Physics Problem Solving}

Rational students tend to analogize the problem with the phenomena that exist in day life to make it easier to find the right solution, which called as analogic problem-solving. This is shown in the excerpt of an interview with R-4 on problem 7 in the following paragraph.

$R$ : Because it feels easier to pull than push, for example when we move the table it's more easily pull than push.

Then the propulsion becomes less. Especially if on the slippery floor, it easier to pull than push and more secure as well. If we push we can fall if the propulsion is too big.

$A$ : then why do you choose to pull with an angle of $60^{\circ}$ ?

$R$ : if $60^{\circ}$ so its mean the direction is upward, so it's easier than $53^{\circ}$. If it is a little downward we will push it by bending (demonstrating). So it will make our movement tough.

Analogies that used in Rational students is influenced by his tendency to favour explanations based on Logic (Kiersey, 1998). The syntax of Rational problem-solving pattern presented in Figure 4.

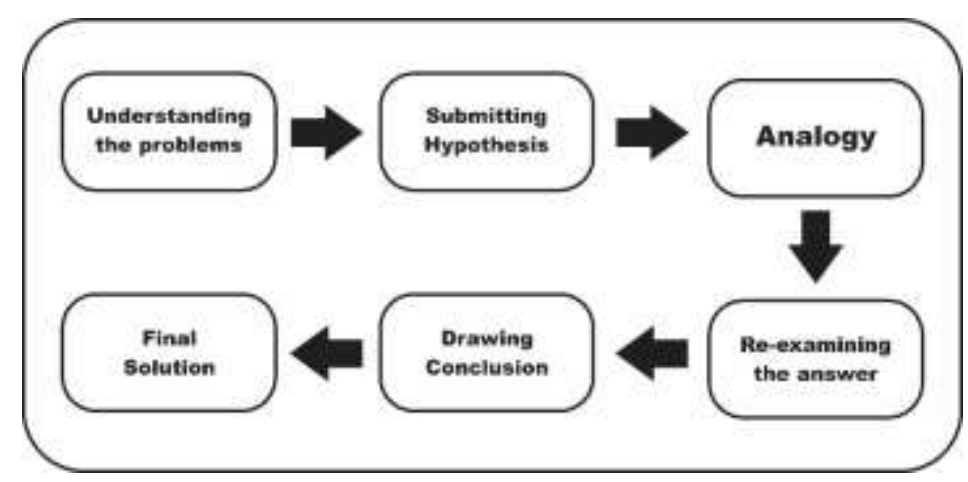

Figure 4. Rational Problem Solving Patterns of Physics

\section{The Personality Type Tendency in Problem Solving Technique}

Any tendency of each personality types can be classified in Table 1. Through this classification, every educator will understand the effective ways to manage changes that occur in students. It is expected that students get more attention to be able to utilize their strengths optimally and gain support to overcome their weaknesses.

Table 1. Characteristics and Problem-Solving Techniques Tendency Based on Personality Type

\begin{tabular}{|c|c|l|l|l|}
\hline $\begin{array}{c}\text { Personality } \\
\text { Type }\end{array}$ & \multicolumn{1}{|c|}{ Goal } & \multicolumn{1}{|c|}{ Characteristics } & \multicolumn{1}{|c|}{ Techniques } & \multicolumn{1}{|c|}{ Weakness } \\
\hline Idealist & $\begin{array}{c}\text { Interpretation } \\
\text { according to the } \\
\text { data }\end{array}$ & $\begin{array}{l}\text { Abstract, find a com } \\
\text { mon thread in every } \\
\text { problem, high interpr } \\
\text { etation value, good s s } \\
\text { elf-assessment }\end{array}$ & $\begin{array}{l}\text { Interpretation of proble } \\
\text { ms with sketches and sy } \\
\text { mbols, posing hypothese } \\
\text { s and problem-solving st } \\
\text { rategies based on predet } \\
\text { ermined concepts, }\end{array}$ & $\begin{array}{l}\text { Associate with } \\
\text { acts, develop rea } \\
\text { listic problem-so } \\
\text { lving }\end{array}$ \\
& & $\begin{array}{l}\text { Using other concepts th } \\
\text { at are still related felt ne } \\
\text { cessary if the old concep } \\
\text { t difficult to understand }\end{array}$ & \\
\hline
\end{tabular}




\begin{tabular}{|c|c|l|l|l|}
\hline $\begin{array}{c}\text { Personality } \\
\text { Type }\end{array}$ & Goal & \multicolumn{1}{|c|}{ Characteristics } & \multicolumn{1}{|c|}{ Techniques } & \multicolumn{1}{|c|}{ Weakness } \\
\hline Artisan & Work efficiently & $\begin{array}{l}\text { Concrete, orientate t } \\
\text { o the current reality, } \\
\text { avoid the things that } \\
\text { are considered compl } \\
\text { icated, have a lot of } \mathrm{p} \\
\text { lanning about the fut } \\
\text { ure, flexible in deter } \\
\text { mining problem solvi } \\
\text { ng }\end{array}$ & $\begin{array}{l}\text { An intuitive approach to } \\
\text { finding hypotheses, eval } \\
\text { uating strategies using a } \\
\text { nalogies, draws conclusi } \\
\text { ons from the results of t } \\
\text { he analogy }\end{array}$ & $\begin{array}{l}\text { Connect the cor } \\
\text { e problems and } \\
\text { concepts of phys } \\
\text { ics in problem-s } \\
\text { olving strategies }\end{array}$ \\
\hline Guardian & $\begin{array}{l}\text { Follow the } \\
\text { existing flow }\end{array}$ & $\begin{array}{l}\text { Realistic, regularity } \\
\text { oriented, avoiding } \\
\text { abstract discussion }\end{array}$ & $\begin{array}{l}\text { Intuition is needed to } \\
\text { determine the hypothesis } \\
\text { and problem-solving plan } \\
\text { when the basic concept } \\
\text { changes }\end{array}$ & $\begin{array}{l}\text { Classify basic } \\
\text { concepts in } \\
\text { finding problem- } \\
\text { solving } \\
\text { strategies, } \\
\text { evaluating } \\
\text { strategies }\end{array}$ \\
\hline Rational & $\begin{array}{l}\text { A real } \\
\text { comparison }\end{array}$ & $\begin{array}{l}\text { Using a logical } \\
\text { reason, oriented to a } \\
\text { real analogy }\end{array}$ & $\begin{array}{l}\text { Contextual } \\
\text { understanding, } \\
\text { adaptation of problem- } \\
\text { solving plans according } \\
\text { to reality, evaluating by } \\
\text { comparing each plan for } \\
\text { finding solutions }\end{array}$ & $\begin{array}{l}\text { Describe the } \\
\text { concept of } \\
\text { physics } \\
\text { according to the } \\
\text { analogy }\end{array}$ \\
\hline
\end{tabular}

\section{CONCLUSION}

The characteristics and techniques that used by each individual are interesting to describe. Idealist type is a good inventor during the process of solving physics problem. The Artisan type is more concerned with the results of the process therefore he will try to finish everything in a way that is easy and fast. The Guardian type encounters complex problems, they find it difficult to elaborate the basic concepts and choose to use intuitive techniques for each problem solving step. Meanwhile, the Rational type likes realistic and logical things, therefore in every step analogizing the problem with a phenomenon in everyday life.

\section{REFERENCES}

Akse, J., Willliam W. H., Rutger, C. M. E. E., Quinten, A. W. R., \& Wim, H. J. M. 2016. Stability and Change in Personality Type Membership and Anxiety in Adolescence. Journal of Adolasence, 4(3): 1-22.

Bransford, J., \& Stein, B. 1984. The IDEAL problem solver. New York: W. H. Freeman.

Brunning, R. H., Schraw, G.J., \& Norby, M.M. 2012. Cognitive Psychology and Instruction Ed. 5. Boston: Pearson.

Dewey, J. 1933. How We Think. Boston: D. C. Health.

Gall, M. D., Gall, J. P., \& Borg, W. R. 2003. Educational Research: an Introduction (7th Edition). New York: Pearson Education Inc.

Jackson, J. J. 2011. The Effects of Educational Experiences on Personality Trait Development. Disertation. Urbana, United State: Univerity of Illinois.

Jessee, S. A., O’Neil, P. N. \& Dosch, R. O. 2016. Matching Student personality Types and Learning Preferences to Teaching Methodologies. Journal of Dental Education. 70(6): 644-651.

Keirsey, D. 1998. Please Understand Me II. United States: Prometheus Nemesis Books.

Moleong, L.J. 2002. Metodologi Penelitian Kualitatif. Edisi Revisi. Bandung: Remaja Rosdakarya. 
Olson, M.H., \& Hergenhahn, B.R., 2013. An Introduction to Theories of Personality, Ed: 8. Terjemahan: Yudi Santoro. Yogyakarta: Pustaka Pelajar.

Panjaitan, B. 2015. Karakteristik Metakognisi Siswa dalam Memecahkan Masalah matematika Berdasarkan Tipe Kepribadian. Jurnal Ilmu Pendidikan, 21(1): 19-28.

Pertiwi, A. D., Masrukan \& Susilo. 2014. Analisis Kemampuan Komunikasi Matematis Melalui Pembelajaran Model 4K Berdasarkan Tipe Kepribadian Peserta Didik Kelas VII, Jurnal Kreano,5(2): 195-204.

Polya, G. 1973. How to Solve It. New Jersey: Pricenton University Press.

Surya, M. 2015. Strategi Kognitif dalam Proses Pembelajaran. Bandung: Alfabeta.

Zanberg, L., John L. Q., Marc N., \& Kees V. O. 2016. Personality-dependent Differences in Problem-solving Performance in a Social Context Reflect Foraging Strategies. Behavioural Processes J. 134(1): 95-102. 